\title{
Der Abbé Galiani als Nationalökonom, Politiker und Philosoph nach seinem Briefwechsel
}

\author{
von \\ Dr. Wilhelm Eduard Biermann \\ a. o. Professor für Nationalökonomie \\ an der Universität Leipzig
}

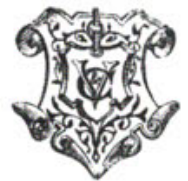

Leipzig

Verlag von Veit \& Comp. 
Sonderabdruck aus:

Volkswirtschaftliche und wirtschaftsgeschichtliche Abhandlungen

W. Stieda

zum 60. Geburtstage dargebracht 